JKEP

Vol 3, No 2, November 2018

ISSN: 2354-6042 (Print)

ISSN : 2354-6050 (Online)

\title{
Faktor-faktor Determinan yang Mempengaruhi Penerimaan Diri Pasien Stroke dengan Keterbatasan Gerak
}

\author{
Nurhalimah, Pipin Farida Yosefina, Omi Haryati \\ Jurusan keperawatan Poltekkes Kemenkes Jakarta III \\ Email:nurhalimahskm@yahoo.co.id
}

\begin{abstract}
Artikel history
Dikirim,Sept30 ${ }^{\text {th }}, 2018$

Ditinjau, Oktt $15^{\text {th }}, 2018$

Diterima,Okt 30 th, 2018
\end{abstract}

\begin{abstract}
ABSTRAK
Kasus stroke di Indonesia meningkat cukup pesat, penderita stroke tidak hanya berusia tua tetapi juga muda. Riskesdas (2013) menggambarkan Prevalensi Stroke tertinggi di Sulawesi Utara (10,8\%o), diikuti DI Yogyakarta (10,3\%o), Bangka Belitung dan DKI Jakarta masing-masing 9,7 per mil. Pasien pasca stroke berdampak terhadap kehidupan pasien, karena individu tidak dapat melakukan banyak hal dan mencapai hal yang terbaik dalam hidupnya, tidak dapat memenuhi tugas perkembangannya, tidak mampu beraktifitas untuk memenuhi kebutuhannya serta interaksi dengan masyarakat di lingkungannya juga terganggu. Tujuan penelitian mendapatkan gambaran faktor determinan terhadap penerimaan diri pasien dengan keterbatasan gerak akibat stroke.Dengan Desain Penelitian: Deskriptif analitik dengan pendekatan cross sectional,Populasipasien yang mengalami stroke. Sampel dalam penelitian ini adalah: pasien paska stroke yang mengalami keterbatasan gerak.Lokasi Penelitian: di wilayah Kec Cipayung, periode dengan teknik pengumpulan data: Menyebarkan instrument penelitian,Analisis data: Analisis Univariat, Bivariat dan MultivariatHasil penelitian ini menyimpulkan bahwa pasien dengan tingkat spiritual yang baik berkontribusi 5 kali untuk menerima diri lebih baik dibandingkan pasien stroke dengan spiritual yang rendah.
\end{abstract}

Kata Kunci: Stroke; penerimaan diri; keterbatasan gerak

\section{ABSTRACT}

Stroke cases in Indonesia are increasing rapidly, stroke sufferers are not only old but also young. Riskesdas (2013) described the highest Stroke prevalence in North Sulawesi (10.8\%o), followed by DI Yogyakarta (10.3\%o), Bangka Belitung and DKI Jakarta, 9.7 per mile respectively. Post-stroke patients have an impact on the lives of patients, because individuals cannot do many things and achieve the best things in their lives, unable to fulfill their development tasks, unable to carry out activities to meet their 
needs and also interfere with the community in their environment. The purpose of the study was to get a description of the determinant factors of self-acceptance of patients with limited mobility due to stroke. With Research Design: Descriptive analytic with cross sectional approach, Population of patients who have a stroke. The sample in this study were: post-stroke patients who experienced limited mobility. Research Location: in the area of Cipayung Subdistrict, period with data collection techniques: Disseminating research instruments, Analysis of data: Univariate, Bivariate and Multivariate Analysis The results of this study concluded that patients with good spiritual levels contributed 5 times better than stroke patients with self spiritual low.

Keywords: Stroke; accepting yourself; limitations of motion

\section{PENDAHULUAN}

Kasus stroke di Indonesia meningkat cukup pesat, penderita stroke tidak hanya berusia tua tetapi juga muda. Riskesdas (2013) menggambarkan prevalensi stroke tertinggi di Sulawesi Utara $(10,8 \%)$, diikuti Yogyakarta (10,3\%o), Bangka Belitung dan DKI Jakarta masing-masing 9,7 per mil.Peningkatan kasus ini berdampak terhadap kehidupan pasien, karena individu tidak dapat melakukan banyak hal dan mencapai hal yang terbaik dalam hidupnya, tidak dapat memenuhi tugas perkembangannya, tidak mampu beraktifitas untuk memenuhi kebutuhannya serta interaksi dengan masyarakat di lingkungannya juga terganggu.

Dampak dari penyakit stroke dapat bersifat fisik, dan psikologis. Gejala fisik paling khas adalah paralisis, kelemahan, hilangnya sensasi di wajah, lengan, atau tungkai di salah satu sisi tubuh, kesulitan berbicara atau memahami (tanpa gangguan pendengaran), kesulitanmenelan, dan hilangnya sebagian penglihatan di salah satu sisi (Feigin, 2007). Perubahan perilaku dan emosional, seperti ansietas, syok, penolakan, marah, stres, dan depresi. (Potter, 2005).Akibatnya individu tidak mampu menyesuaikan diri dengan keadaannya.

Penelitian Masyithah (2012) menunjukkan rata-rata pasien stroke tidak menerima keadaannya, sedangkan penelitian oleh Herawati (2014) menunjukkan bahwa pasien stroke mengalami konflik emosi akibat penurunan fungsi dan perubahan tubuh, bahkan pasien dapat berisiko melakukan perilaku maladaptif. Penelitian lain yang dilakukan Kustiawan (2013) menyebutkan bahwa pasien stroke mengalami tingkat kecemasan yang bervariatif, sebanyak $71,8 \%$ pasien mengalami kecemasan 
sedang, $17,9 \%$ mengalami kecemasan berat, hanya $10,3 \%$ yang mengalami kecemasan ringan. Sebahagian besar pasien merasa dirinya tidak berguna lagi karena hidup mereka lebih banyak bergantung pada orang lain, selain itu pasien akan merasa dirinya cacat dan kecacatan ini menyebabkan citra diri terganggu, merasa diri tidak mampu, tidak berguna, serta menjadi beban bagi keluarga.

Kondisi religious berpengaruh terhadap penerimaan pasien dengan religiusitas yang tinggi maka pasien akan bisa menerima kondisinya dengan ikhlas dengan segala kekurangan dan kelemahannya.Gangguan fungsi syaraf pada pasien stroke menimbulkan gejala antara lain: kelumpuhan wajah atau anggota badan, bicara tidak lancar, bicara tidak jelas (pelo), mungkin perubahan kesadaran, gangguan penglihatan, dan lain-lain. Akibat stroke pasien merasa tidak berharga karena kelemahannya, akibatnya pasien tidak mengalami gangguan dalam penerimaan diri.

Stuart (2013) berpendapat bahwa penerimaan diri adalah sikap yang merupakan rasa puas pada kualitas dan bakat, serta pengakuan akan keterbatasan diri. Dengan demikian dapat dikatakan bahwa penerimaan diri merupakan aset pribadi yang sangat berharga. Calhoun dan Acocella (dalam Novida, 2007) mengatakan penerimaan diri akan membantu individu dalam menyesuaikan diri sehingga sifat-sifat dalam dirinya seimbang dan terintegrasi. Hal ini didukung penelitian Sumbago, Sulisno dan Darwati. 2015, yang menemukan bahwa respon penerimaan penderita stroke untuk menerima kondisinya sebanyak $32,6 \%$, kurang menerima kondisinya sebanyak $54,3 \%$, dan tidak menerima kondisinya sebanyak $13,0 \%$. Rendahnya penerimaan diri pada pasien menandakan bahwa pasien masih dalam kondisi depresi.

Berbeda dengan hasil penelitian kualitatif yang dilakukan Aquinaldi (2013), yang menemukan bahwaresponden yang diteliti tetap dapat menerima kondisinya, dapat melihat kelebihan dan kekurangan diri mereka setelah terkena stroke. Gambaran diri yang positif membuat mereka dapat menyesuaikan diri dengan baik. Hal ini menunjukkan bahwa pasien masih dapat melihat hal yang 
baik dari diri mereka walaupun mereka terkena stroke.Factor yang berpengaruh terhadap penerimaan diri pasien stroke yaitu karakteristik demografi, perubahan citra tubuh dan penurunan harga diri. Selain itu mekanisme kopingdan strategi koping yang digunakan, serta spiritualitasjuga merupakan faktor determinan terhadap penerimaan diri pasien stroke. Peran dan dukungan keluarga juga berpengaruh secara signifikan terhadap proses rehabilitasi pada pasien stroke.

Berdasarkan latar belakang di atas, peneliti tertarik untuk mengetahui factor determinan terhadap penerimaan diri pasien dengan keterbatasan gerak akibat stroke.Tujuan penelitianuntuk mengetahui gambaran faktor determinan terhadap penerimaan diri pasien dengan keterbatasan gerak akibat stroke.

\section{METODE}

Penelitian menggunakan disain deskriptif analitik dengan pendekatan cross sectionalPopulasi adalah pasien yang mengalami stroke. Sampel dalam penelitian ini adalah : pasien paska stroke yang mengalami keterbatasan gerak dengan kriteria inklusi: 1) pasien terdiagnosa medis mengalami stroke; 2) Pasien mengalami keterbatasan dalam ADL; 3) mampu berkomunikasi.Strategi sampling menggunakan cluster multistage method.Jumlah sampel adalah56 orang.

Lokasi penelitian di wilayah Kecamatan Cipayung dan waktu penelitian periode Januari sampai dengan September 2018. Tehnik pengumpulan data dilakukan dengan menyebarkan instrument penelitian kepada responden. Analisis data yang digunakan adalah: Analisis Univariat, Bivariat dan Multivariat

\section{HASIL PENELITIAN DAN PEMBAHASAN}

1. Karakteristik Responden dengan Keterbatasan Anggota Gerak Akibat Stroke

Tabel 1 memperlihatkan usia ratarata respondenberada dalam rentang usia dewasa dan dewasa tengah. Berdasarkan hasil tabel 1 dapat disimpulkan bahwa sebahagian besar responden berjenis kelamin laki-laki (55.4 \%), berada dalam kelompok usia dewasa tengah dan dewasa (50\%), tidak bekerja ada $80.3 \%$ dengan pendidikan tinggi sebesar $76.8 \%$, ada $83.7 \%$. 
Tabel 1

Karakteristik Responden

Dengan Keterbatasan Anggota Gerak Akibat Stroke, Tahun 2018

$(\mathrm{N}=56)$

\begin{tabular}{llcc}
\hline \multicolumn{1}{c}{ Variabel } & Kelompok & $\mathrm{N}$ & $\%$ \\
\hline Jenis Kelamin & Laki-laki & 31 & 55.4 \\
& Perempuan & 25 & 44.6 \\
Total & & 56 & 100 \\
\hline Umur & Dewasa Tengah & 28 & 50 \\
& Dewasa & 28 & 50 \\
Total & & 56 & 100 \\
& Bekerja & 11 & 19.7 \\
Pekerjaan & Tidak Bekerja & 45 & 80.3 \\
\multirow{2}{*}{ Total } & & 56 & 100 \\
\hline Pendidikan & Rendah & 13 & 23.2 \\
\multirow{2}{*}{ Total } & Tinggi & 43 & 76.8 \\
& & 56 & 100 \\
\hline Status Perkawinan & Kawin & 47 & 83.9 \\
\multirow{2}{*}{ Total } & Tidak Kawin & 9 & 16.1 \\
\hline
\end{tabular}

2. Hubungan antara Karakteristik Responden dengan Penerimaan Diri pada Pasien dengan Keterbatasan

Gerak akibat Stroke

Berdasarkan karakteristik responden didapatkan bahwa hasil usia rata-rata responden berusia 45-64 tahun. Rentang usia 45-64 tahun adalah termasuk dalam kategori lansia, dimana pada usia ini manusia mengalami perubahan secara fisik, biologis, kejiwaan dan sosial. Perubahan ini akan memberikan pengaruh pada kesehatan dan seluruh aspek kehidupannya. Usia merupakan faktor yang mempengaruhi kualitas hidup seseorang, karena pada usia ini seseorang sudah mengalami penurunan fungsi organ-organ tubuh. Hal ini didukung oleh penelitian Rahmi (2014) yang membuktikan bahwa usia mempengaruhi kualitas hidup penderita pasca stroke. 
Tabel 2

Hubungan Antara Karakteristik Responden dengan Penerimaan Diri pada Pasien dengan Keterbatasan Gerak Akibat Stroke,Tahun 2018(N=56)

\begin{tabular}{|c|c|c|c|c|c|c|c|}
\hline \multirow[t]{3}{*}{ Variabel } & \multicolumn{5}{|c|}{ Penerimaan diri } & \multirow{3}{*}{ OR } & \multirow{3}{*}{$\mathrm{p}$-value } \\
\hline & \multicolumn{2}{|c|}{ Baik } & \multicolumn{2}{|c|}{ Kurang Baik } & \multirow[t]{2}{*}{ Total } & & \\
\hline & $\mathrm{N}$ & $\%$ & $\mathrm{~N}$ & $\%$ & & & \\
\hline \multicolumn{8}{|l|}{ Umur } \\
\hline Dewasa Tengah & 18 & 64.3 & 10 & 35.7 & $28 \quad 100 \%$ & 2.077 & \\
\hline Lansia & 13 & 46.4 & 15 & 53.6 & $28 \quad 100 \%$ & $0.711-6.067$ & 0.282 \\
\hline Total & 31 & 55.4 & 25 & 44.6 & $56 \quad 100 \%$ & & \\
\hline \multicolumn{8}{|l|}{ Pendidikan } \\
\hline Tinggi & 28 & 65.1 & 15 & 34.9 & $43100 \%$ & 6.222 & 0.019 \\
\hline Rendah & 3 & 23.1 & 10 & 76.9 & $13100 \%$ & $1.482-26.119$ & \\
\hline Total & 31 & 55.4 & 25 & & $56100 \%$ & & \\
\hline \multicolumn{8}{|l|}{ Jenis Kelamin } \\
\hline Laki-laki & 17 & 54.8 & 14 & 45.2 & $31100 \%$ & 0.954 & 1.00 \\
\hline Perempuan & 14 & 56 & 11 & 44 & $25100 \%$ & $0.330-2.754$ & \\
\hline Total & 31 & 55.4 & 25 & 44.6 & $56100 \%$ & & \\
\hline \multicolumn{8}{|l|}{ Pekerjaan } \\
\hline Bekerja & 9 & 81.8 & 2 & 18.2 & $11100 \%$ & 5.464 & 0.011 \\
\hline Tidak bekerja & 30 & 66.6 & 15 & 33.4 & $45100 \%$ & $1.627-18.357$ & \\
\hline Total & 39 & 69.6 & 17 & 30.3 & $56100 \%$ & & \\
\hline \multicolumn{8}{|l|}{ Staus Perkawinan } \\
\hline Kawin & 40 & 85 & 7 & 15 & $47100 \%$ & 2.429 & 0.004 \\
\hline Tidak kawin & 7 & 77.7 & 2 & 22.3 & $9100 \%$ & $1.226-4.811$ & \\
\hline Total & 47 & 83.9 & 9 & 16.07 & $56100 \%$ & & \\
\hline
\end{tabular}

Berdasarkan jenis kelamin dari responden pada Karakteristik responden juga dapat mempengaruhi kesejahteraan spirtual responden seperti usia. Karakteristik responden berdasarkan usia yang terbanyak adalah rentang usia
45-64,Usia dapat mempengaruhi kesejahteraan spiritual seseorang, semakin tua usia seseorang maka akan semakin baik kesejahteraan spiritual orang tersebut. penelitian ini didapatkan bahwa laki-laki lebih dominan 
megalami kualitas hidup yang tinggi. Hal ini didukung oleh Zahilin, Viedran, dan Mirela (2010) bahwa jenis kelamin mempengaruhi kualitas hidup penderita pasca stroke. Mereka membuktikan dalam penelitian mereka bahwa lakilaki mempunyai skor kualitas hidup yang lebih tinggi daripada perempuan. Laki-laki menunjukkan keadaan yang lebih baik dalam hal fisik, psikis, dan ingatan, sedangkan perempuan lebih banyak mengalami kecemasan setelah terkena stroke. Hasil penelitian ini sesuai dengan pernyataan Masiyita, (2012) menyatakan bahwa peranan dan dukungan sosial diharapkan mampu meminimalisir ketegangan psikologis penderita dan dapat memberikan semangat untuk bangkit dan sembuh.

3. Hubungan Antara Faktor Internal dan Eksternal yang Mempengaruhi Penerimaan DiriPasien Stroke dengan Keterbatasan Gerak Akibat Stroke

Tabel 3

Hubungan Antara Faktor Internal dan Eksternal yang Mempengaruhi Penerimaan

Diripasien Stroke Dengan Keterbatasan Gerak Akibat Stroke, Tahun 2018 ( n. 56)

\begin{tabular}{|c|c|c|c|c|c|c|c|}
\hline \multirow[t]{3}{*}{ Variabel } & \multicolumn{5}{|c|}{ Penerimaan diri } & \multirow{3}{*}{$\mathrm{OR}(\mathrm{CI})$} & \multirow{3}{*}{ p-value } \\
\hline & \multicolumn{2}{|c|}{ Baik } & \multicolumn{2}{|c|}{ Kurang Baik } & \multirow[t]{2}{*}{ Total } & & \\
\hline & $\mathrm{N}$ & $\%$ & $\mathrm{~N}$ & $\%$ & & & \\
\hline \multicolumn{8}{|l|}{ Dukungan Keluarga } \\
\hline Memadai & 24 & 55.8 & 19 & 35.7 & $43100 \%$ & 1.083 & 1.00 \\
\hline Kurang Memadai & 7 & $53 / 8$ & 6 & 53.6 & $13100 \%$ & $0.312-3.782$ & \\
\hline Total & 31 & 55.4 & 25 & 44.6 & $56100 \%$ & & \\
\hline \multicolumn{8}{|l|}{ Spiritual } \\
\hline Baik & 28 & 65.1 & 15 & 34.9 & $43100 \%$ & 2.389 & 0.001 \\
\hline Kurang baik & 3 & 23.1 & 10 & 76.9 & $13100 \%$ & $1.680-3.398$ & \\
\hline Total & 31 & 55.4 & 25 & 44.6 & $56100 \%$ & & \\
\hline \multicolumn{8}{|l|}{ Citra Tubuh } \\
\hline Baik & 17 & 54.8 & 14 & 45.2 & $31100 \%$ & 4.125 & 0.000 \\
\hline Kurang baik & 14 & 56 & 11 & 44 & $25100 \%$ & $2.257-7.540$ & \\
\hline Total & 31 & 55.4 & 25 & 44.6 & $56100 \%$ & & \\
\hline
\end{tabular}


Peran dan dukungan keluarga berpengaruh secara signifikan terhadap proses rehabilitasi pada pasien stroke. Bleiberg (dalam Kaplan, 1994) serta pernyataan dari Taylor (1998). Pernyataan kedua ahli tersebut, sesuai dengan hasil penelitian ini yang menyimpulkan bahwa keluarga memainkan peranan yang sangat penting dalam hasil rehabilitasi pada pasien stroke, yaitu sebesar $80 \%-90 \%$ perawatan kesehatan lebih diberikan oleh keluarga daripada oleh program pendukung formal.

Hal ini disebabkan karena pada orangorang yang mengalami stroke, dalam melakukan kegiatan sehari-hari akan sangat tergantung pada orang lain, terutama keluarga terdekat dan juga lingkungan sosial di sekitar. Selain itu hasil penelitian ini juga sesuai dengan penelitian yang dilakukan oleh Christine dan Sri Eka (2012) pada pasien Kanker payudara yang menunjukan hasil bahwa $60 \%$ pasien kanker payudara yang menjalani kemoterapi memiliki harga diri tinggi, hal ini disebabkan adanya dukungan yang diberikan oleh keluarga. Penelitian Rohardija, Komariah \& Adiningsih
(2012) juga mendukung pernyataan tersebut.

Istri maupun suami yang bertugas sebagai primary caregiver akan merasakan dampak dari kondisi fisik dan psikologis yang dialami oleh pasangannya pasca serangan stroke. Stephens \& Clark (1997) mengatakan bahwa menyesuaikan diri dengan pasangan yang mengalami penyakit kronis dan fatal memberikan tantangan serius bahkan pada pasangan yang paling bahagia. Beberapa keluarga dapat menyesuaikan diri dengan baik terhadap kondisi pasien stroke, tetapi beberapa keluarga lainnya tidak mampu menyesuaikan diri dengan baik pada perubahan hubungan dan harmonisasi perkawinan selalu menurun (Newman dalam Rodiatul \& Dewi 2010). Peran sebagai primary caregiver yang dilakukan oleh pasangan dapat menimbulkan dampak yang positif dan juga negatif.

Dampak positif yang dirasakan antara lain pasangan merasa lebih dibutuhkan kehadirannya dalam membantu kegiatan pasien sehari- hari, mengurus dan menjaga pola makan pasien, serta mendampingi pasien saat terapi, merasa 
lebih berguna dengan memberikan makna lebih bagi kehidupan pasangannya, memperkuat hubungannya dengan orang lain, meningkatkan kualitas diri secara spiritual, dan juga memperkuat komitmen yang lebih intens terhadap pasangan melalui kegiatan caregiving yang diberikan kepada pasangan. (Robert, 2006; Teasell, Foley, Salter, Bhogal, Juntai \& Speechley, 2011; Cempaka 2012).

Selain dampak positif, peran pasangan sebagai primary caregiver memberikan dampak negatif, terkait aspek fisik, emosional, sosial dan finansial. Dengan sedikit persiapan dan dukungan secara professional yang terbatas, ketegangan dari pasangan yang menjadi pengasuh dapat mengarah ke distress level yang tinggi. Stres negatif yang tinggi ini akan menghasilkan bentuk stres yang bermacam-macam seperti depresi, kecemasan, kemarahan, terganggunya gaya hidup serta hubungan dengan orang lain, kelelahan dan perasaan terisolasi (Anderson, dkk dalam Robert.
J, dkk, 2006). Seperti yang telah diuraikan mengenai dampak positif dan negatif dalam merawat yang dirasakan oleh pasangan sebagai primary caregiver, maka proses caregiving dapat menjadi hal yang menekan. Proses caregiving dapat menyebabkan pasangan mengalami depresi, perasaan sedih dan tertekan, kelelahan fisik, dan perubahan pada hubungan sosial.

Hasil penelitian ini menyimpulkan bahwa kematangan spiritual berpengaruh 2 kali terhadap penerimaan diri pasien stroke dengan keterbatasan gerak. Hal ini sesuai dengan pernyatan Aderson (dalam Sugiarti, 2008) menyatakan bahwa kematangan spiritual berarti individu telah berhasil menerima kelebihan dan kekurangan diri apa adanya termasuk didalamnya bagaimana individu mampu menerima citra tubuhnya dengan baik.

\section{Analisis MultivariatFaktor-faktor Determinan yang Mempengaruhi Penerimaan Diri Pasien Stroke dengan Keterbatasan Gerak}


Tabel 4

Analisis Multivariat Faktor-faktor Determinan yang Mempengaruhi Penerimaan Diri Pasien Stroke dengan Keterbatasan Gerak

\begin{tabular}{lllllllll}
\hline Variabel & B & S.E & Walt & df & sig & $\begin{array}{l}\text { Exp } \\
\text { (B) }\end{array}$ & $\begin{array}{l}\text { 95 \% C.I } \\
\text { Lower }\end{array}$ & Upper \\
\hline Spiritual & 20.038 & 9.163 & 0.000 & 1 & 0.998 & 5.037 & 1.109 & 7.946 \\
\hline Citra Tubuh & 21.586 & 7.422 & 0.000 & 1 & 0.998 & 2.369 & 1.268 & 6.555 \\
\hline Pendidikan & 1.204 & 1.169 & 1.061 & 1 & 0.803 & 3.333 & 1.236 & 5.855 \\
\hline
\end{tabular}

Tabel 4 memperlihatkan bahwa pasien dengan tingkat spiritual yang baik berkontribusi 5 kali untuk menerima diri lebih baik dibandingkan pasien stroke dengan spiritual yang rendah.Kesejahteraanspiritual

memberikan kontribusi terhadap kualitashidup. Kemampuan seseorang dapat dilihat darikualitas dalam memaknai peluang yang diperolehdalam hidupnya, sebagai hasil interaksi denganlingkungan dan pencapaian keselarasan hidup.Kesejahteraan spiritual yang baik ditandai denganseseorang memiliki hubungan yang harmonisdengan diri sendiri, harmonis dengankomunitas/orang lain, harmonis denganlingkungan, dan hubungan yang harmonis denganTuhan (Hanie, 2010).Fisher (2010)

Hasil penelitian ini sesuai dengan penelitian pendahuluan yang dilakukan kepada 10 pasien pasca stroke yangdirawat di Ruang Poli Saraf RSUD Ulin Banjarmasin didapatkan hasil 4 dari 10 pasienstroke memiliki kesejahteraan spiritual dankualitas hidup yang baik ditandai dengan, saatwawancara pasien mengatakan bahwa merekapercaya kepada Tuhan bahwa Tuhan tidak akanmemberikan cobaan diluar batas kemampuanmereka. Dengan penyakit yang dialaminya pasienmengatakan merasa lebih dekat dengan Tuhan,lebih berserah diri kepada Tuhan dan mengambilhikmah dari penyakitnya. Pasien mengatakandapat menerima semua perubahan dalam dirinyakarena kondisi penyakitnya dan pasienmengatakan keluarga selalu mendukung pasienuntuk berobat dan menemani pasien saat berobatke Rumah Sakit sehingga pasien mempunyaisemangat untuk hidup dan sembuh.Sedangkan 6 dari 10 pasien pasca strokememiliki kesejahteraan spiritual dan kualitashidup yang kurang 
baik dan saat diwawancarairata-rata pasien mengatakan tidak berdaya danTuhan tidak adil kepada mereka, mereka tidakpernah bertanya dalam dirinya apa makna dantujuan dalam hidupnya. Mereka menyalahkanTuhan dengan kondisinya dan mengapa Tuhanmemberikan penyakit ini pada dirinya apasebenarnya dosa yang dia perbuat sehinggamendapatkan hukuman seperti ini. Pasienmengatakan karena penyakit yang dialaminyamembuat pasien tidak berdaya dan tidak bergunalagi dalam hidupnya, pasien tidak dapatmenerima perubahan kondisi kesehatannyakarena dengan kondisinya ini akan menjadibeban untuk keluarganya karena dalam segalaaktivitasnya harus dibantu oleh orang lain.

Hasil penelitian ini sejalan dengan hasil penelitian yang dilakukan oleh Novia dan Herdyan tentang kesejahteraanspiritual pasien pasca stroke di Ruang Poli SarafRSUD Ulin Banjarmasin dapat disimpulkanbahwa kebutuhan spiritual pasien pasca strokeharus terpenuhi sehingga mampu mencapai keadaanyang sejahtera karena didukung dengan aktivitas kerohanian secara personal yang baik. Hal yang juga turut mempengaruhi adalah diripasien sendiri yang sudah bisa menyesuaikandengan keadaannya sehingga pasien lebihmenerima kondisi, yang membuat pasienberdamai dengan dirinya sendiri, orang lain, alam sekitarnya dan juga dengan Tuhan.

\section{SIMPULAN}

Pasien dengan keterbatasan gerak akibat stroke dengan spiritual yang baik memiliki penerimaan diri 5 kali lebih baik dibandingkan dengan pasien yang memiliki spiritual yang kurang. Hasil penelitian memperlihatkan bahwa dibutuhkan suatu kebijakan untuk implementasi terapi kelompok pada keperawatan jiwa yaitu self help group. Implementasi terapi kelompok melibatkan keluarga dan masyarakat sebagai bentuk pemberdayaan masyarakat.

\section{DAFTAR RUJUKAN}

Aquinaldi, R. 2013. Gambaran Penyesuaian Diri Pada Penderita Stroke Iskemik Usia Dewasa Muda. Jurnal NOETIC, Vol 3, No. 2.

Asiyah. 2013. Psychological Well Being Penyandang Gagal Ginjal. Jurnal Penelitian Psikologi 2013, Vol. 04, No. 01, 35-45. Surabaya: IAIN Sunan Ampel Surabaya. 
Hartono. 2010. Buku Ajar Keperawatan Jiwa. Jakarta: Salemba Medika.

Hasan, A.B.P. 2008. Pengantar Psikologi Kesehatan Islam. Jakarta : PT Raja Grafindo Persada

Herawati. (2014). Studi Fenomenologi Pengalaman Perubahan Citra Tubuh Pada Klien Kelemahan Pasca Stroke Di RS Dr M Djamil Kota Padang. Jurnal Keperawatan Jiwa . Volume 2, No. 1, Mei 2014; 31-40.

Hurlock. 2010. Psikologi Perkembangan. Jakarta: EGC.

Junaidi. 2011. Stroke Waspadai Ancamannya. Yogyakarta: Andi

Kustiawan. 2013. Gambaran Tingkat Kecemasan Pada Pasien Stroke Iskemik Di Ruang V Sakit Umum Kota Tasikmalaya. Jurnal Kesehatan Bakti Tunas Husada, Volume 12, No 1 Agustus 2014.

Mulyatsih, E. 2008. Petunjuk perawatan pasien pasca stroke di rumah. Jakarta:Balai penerbit FKUI

Novvida. (2007). Gangguan Psikiatrik pada Penderita Stroke. Jogjakarta: Graha Ilmu

Potter \& Perry .2005. Buku Ajar Fundamental Keperawatan: Konsep, Proses Dan Praktik, edisi 4 trans. Asih, Y, et.al , EGC, Jakarta.
Rohadirja. 2012. Konsep Diri pada Pasien Stroke Ringan di Poliklinik Saraf RSUD Sumedang, Jurnal, Terpublikasi, diakses tanggal 31 Januari 2018, <journals.unpad.ac.id>

Santrock, J. W. 2006. Human adjustment. New York: McGraw-Hill.

Sarafino, E. P. 2008. Health psychology (6th ed.). New York: John Wiley \&Sonc. Inc.

Stuart, G.W. 2013. Principles and Practice of Psychiatric Nursing. 9th ed. Missouri: Mosby Elsevier

Sumbogo, A., Sulisno, M., \& Darwati, L.E. 2015. Gambaran Respon Psikologis Penderita Stroke. Jurnal Ilmiah Stikes Kendal, Vol. 5, No. 1, hal.29-37.

Volona, F.A., \& Ernawati, N. 2016. Hubungan Konsep Diri (Citra Diri Dan Harga Diri) Dengan Strategi Koping Pada Penderita Pasca Stroke Di Wilayah Kerja Puskesmas Kedungwuni I Kabupaten Pekalongan. Stikes Pekalongan. Skripsi Tidak Dipublikasikan.

Yastroki. 2012. Setiap Tahun 500.000 Penduduk Indonesia Terkena Stroke. Yayasan Stroke Indonesia Edisi Januari 2012. Diakses melalui: http://www.yastroki.or.id, pada tanggal 31 Januari 2018. 